\title{
Philaenus spumarius: when an old acquaintance becomes a new threat to European agriculture
}

\author{
D. Cornara ${ }^{1} \cdot$ D. Bosco $^{2,3} \cdot$ A. Fereres ${ }^{1}$
}

Received: 20 August 2017 / Revised: 21 December 2017 / Accepted: 1 March 2018

c) Springer-Verlag GmbH Germany, part of Springer Nature 2018

\begin{abstract}
The unique color pattern polymorphism and the foamy nymphal case of the meadow spittlebug Philaenus spumarius have attracted the attention of scientists for centuries. Nevertheless, since this species has never been considered a major threat to agriculture, biological, ecological and ethological data are missing and rather scattered. To date this knowledge has become of paramount importance, in view of the discovery of $P$. spumarius main role in the transmission of the bacterium Xylella fastidiosa in Italy, and possibly in other European countries. The aim of this review is to provide a state of the art about this species, with particular focus on those elements that could help developing environmental friendly and sustainable control programs to prevent transmission of X. fastidiosa. Moreover, recent findings on the role of the meadow spittlebug as vector of the fastidious bacterium within the first reported European bacterium outbreak in Apulia (South Italy) will be discussed.
\end{abstract}

Keywords Spittlebug $\cdot$ Olive $\cdot$ Almond $\cdot$ Grapevine $\cdot$ Control options $\cdot$ Reservoirs $\cdot$ Vectors

\section{Key message}

- The meadow spittlebug Philaenus spumarius plays a major role in the spread of Xylella fastidiosa in the first European outbreak of the bacterium in the Apulia region (Southern Italy).

- Biological, ecological and ethological data about P. spumarius are rather scattered and need further investigations.

- Here, we comprehensively collected scattering data and unpublished information about the meadow spittlebug and its relationship with the fastidious bacterium. Fur-

Communicated by N. Desneux.

A. Fereres

a.fereres@csic.es

1 Instituto de Ciencias Agrarias, Consejo Superior de Investigaciones Cientificas, ICA-CSIC, Calle Serrano 115 dpdo, 28006 Madrid, Spain

2 Università di Torino, Dipartimento di Scienze Agrarie, Forestali e Alimentari, Largo Paolo Braccini, 2, 10095 Grugliasco, TO, Italy

3 Istituto per la Protezione Sostenibile delle Piante, Consiglio Nazionale delle Ricerche, Strada delle Cacce, 73, 10135 Torino, Italy thermore, we reviewed the known control tactics and proposed new management strategies against this pest.

\section{Introduction}

Spittlebugs and their nymphal case have received attention from naturalists for centuries. Starting from Saint Isidore from Seville in the sixth century, and later with Moffet and Linnaeus, many scientists devoted their attention to these unique creatures coming from a "frothy sticky whitish dew" (Moffet 1685, cited in Weaver and King 1954). In the literature, spittle masses have been called in many ways: Gowk's spittle, frog spit, snake spit, witch's spit and wood sear, beside cuckoo spittle, since the cuckoo bird migrate in Europe at the same time the first masses appear (Svanberg 2016). It has also been suggested that these masses generate small locust (Yurtsever 2000). The meadow spittlebug Philaenus spumarius L. (1758) belongs to the order Hemiptera, superfamily Cercopoidea, family Aphrophoridae. The name spittlebug came from the shell built up by the nymphs mixing fluid voided from the anus and a secretion produced by glands located between the 7 th and the 8 th abdominal sternites. Air bubbles are introduced within the spittle by means of caudal appendages and a ventral tube formed by abdominal tergites (4th to 9th) bent downward (Yurtsever 
2000). Due to its polymorphism, more than 50 synonyms had been given to P. spumarius, as reported by Nast (1972). The meadow spittlebug was commonly called Philaenus leucophtalmus in the early literature, as for example in Severin (1950) and Weaver and King (1954). The taxonomical confusion was solved when, in 1961, the International Commission of Zoological Nomenclature decided for the only valid specific name of $P$. spumarius (Yurtsever 2000). The large body of literature on $P$. spumarius deals mainly with the genetic basis of adult color polymorphism, and the damage caused by nymphs to strawberry and alfalfa, when the insect was introduced in USA (Weaver and King 1954). Now, we know that this ubiquitous, common and locally very abundant insect is the main vector of the bacterium Xylella fastidiosa in the Apulia region of Italy and has the potential to spread it in all the other European regions where the pathogen is present. Nevertheless, since the meadow spittlebug has never been considered an agricultural pest in Europe before the introduction of $X$. fastidiosa, its biology, ecology and ethology have never been investigated continuously and in a comprehensive way. Therefore, the main aim of this manuscript is to provide an updated and critical state of the art about $P$. spumarius, mainly focusing on those elements that could help developing an environmental friendly and sustainable control strategy to prevent $X$. fastidiosa spread.

\section{Taxonomy and description}

Until the 1980s, only three species belonging to the genus Philaenus were known: the Holarctic P. spumarius; the Mediterranean species $P$. signatus (inhabiting the Balkans and the Middle East); and P. tesselatus (Southern Iberia and Maghreb); this latter often considered a subspecies or a synonym of P. spumarius (Nast 1972). Starting from the 1990s, thanks to in-depth studies carried out across the Mediterranean, five further species of the genus have been described: P. loukasi (southern Balkans), P. arslani (the Middle East), P. maghresignus (Maghreb and southern Spain), P. italosignus (southern Italy and Sicily) and $P$. tarifa (southern Iberia). The eight species are sympatric with $P$. spumarius and partially allopatric with each other (Maryanska-Nadachowska et al. 2012). The proteobacterium Wolbachia could have played a role in the speciation of $P$. spumarius, since it is almost exclusively present in northeastern mitochondrial clade (Lis et al. 2015). Currently, the species can be distinguished according to anal tube and male genitalia morphology in two groups: the "spumarius" group ( $P$. spumarius, $P$. tesselatus, $P$. loukasi and $P$. arslani) and the "signatus" group (P. maghresignus, $P$. italosignus, $P$. signatus and $P$. tarifa) (Drosopoulos and Remane 2000). Another classification takes into account nymphal food plants and allows a differentiation in three main groups: $P$. signatus, $P$. italosignus,
$P$. maghresignus and $P$. tarifa, whose nymphs elect the lily Asphodelus aestivalis L. (1753) as their main host plant; $P$. loukasi and $P$. arslani, whose nymphs develop on xerophilic plants; and $P$. spumarius and $P$. tesselatus, that thrive on monocotyledonous and dicotyledonous plants, although the former is likely to prefer dicots (Drosopoulos 2003). According to Maryanska-Nadachowska et al. (2012), the genus Philaenus is monophyletic, this claim being supported by morphological, ecological and chromosomal data. P. spumarius is extremely varying in color, going from unicolorous yellowish white to unicolorous black, with several intermediate morphs. Most of these were originally described as species. Furthermore, recently two new species belonging to the genus Philaenus, namely P. elbusiarnus and P. iranicus, have been described in Iran (Tishechkin 2013). A detailed morphological and phylogenetic description of the species is out of the purpose of this review; for papers regarding these issues, please refer to Delong and Severin (1950), Ossiannilsson (1981), Berry and Willmer (1986), Stewart and Lees (1996), Quartau and Borges (1997), Drosopoulos (2003), Maryańska-Nadachowska et al. (2012), Rodrigues et al. (2014), and further references.

\section{Geographical range}

Philaenus spumarius is widely distributed, covering most of the Palearctic regions and extending to Nearctic, as well as most of the temperate regions of earth and oceanic islands (Stewart and Lees 1996; Drosopoulos and Asche 1991; Drosopoulos and Remane 2000). Its distribution ranges from north Lapland to the Mediterranean in Europe, including Turkey. It has been reported for North Africa, several parts of the former Soviet Union, Afghanistan, Japan, USA, Canada, Azores, Hawaii and New Zealand (Yurtsever 2000). The meadow spittlebug was probably introduced in new continents, as North America, as overwintering eggs in straw stubble (Whittaker 1973). Its distribution in Europe and worldwide has been summarized by EFSA (2015). In Greece, Drosopoulos and Asche (1991) reported P. spumarius at an altitude ranging from the sea level to more than $2000 \mathrm{~m}$. Climate change may significantly have affected the distribution of P. spumarius: Karban and Strauss (2004) suggested that the species northward shift in California since 1988 is related to variations in humidity and temperature.

\section{Host plants and feeding behavior}

P. spumarius is highly polyphagous and occurs in most of the terrestrial habitats (Stewart and Lees 1996). According to Maryanska-Nadachowska et al. (2012), the common ancestor of the species belonging to the genus Philaenus may have used 
lily as its main host plant, a character that still remains in $P$. maghresignus, $P$. italosignus, $P$. tarifa and $P$. signatus. On the contrary, the exploitation of a wide range of hosts belonging to monocotyledonous and dicotyledonous may have been the leading factor promoting the geographical expansion of the species. $P$. spumarius is a xylem feeder, either as nymph or adult: The spittlebug ingests considerable amount of sap from the main transpiration stem without causing vessels cavitation, overcoming dramatically high tension reaching -10 bars and showing a mean excretion rate of 280 times its body weight in $24 \mathrm{~h}$ (Wiegert 1964; Horsfield 1978; Crews et al. 1998; Malone et al. 1999; Watson et al. 2001; Ponder et al. 2002). The association with symbionts potentially relaxes the severe energy limitations related to xylem sap feeding, being the xylem sap nutritionally poor and energetically costly to extract (Thompson 2004; Koga et al. 2013). Nymphs and adults feed preferentially on actively growing parts (Mundinger 1946; Wiegert 1964). Nitrogen-fixing legumes and other plants with high amino acids concentration in the xylem sap (Medicago sativa L. (1753), Trifolium sp. L., Vicia spp. L., and Xanthium strumarium L. (1753)) are the preferred hosts (Horsfield 1977; Thompson 1994). Overall, P. spumarius seems to prefer plants that transport fixed nitrogen as amino acids and amides than those that transport fixed nitrogen as ureides (Thompson 1994). Nymphal excretion rate has been proven to be positively correlated with amino acids concentration in the xylem sap (Horsfield 1977). Nymphs and adults thrive on various plants in habitats moist enough to provide them with sufficient humidity to keep them alive, such as meadows, abandoned fields, waste grounds, roadsides, streamsides, hayfields, marshlands, parks, gardens and cultivated fields (Yurtsever 2000). Gulijeva (1961) reported cereals, Asteraceae, legumes and Lamiaceae as the most favorable hosts. Ossiannilsson (1981) states that $P$. spumarius is the most polyphagous insect currently known, with a host lists that exceed 1000 plants. Dicotyledonous plants tend to be used more often than monocotyledonous (Wiegert 1964; Halkka et al. 1967, 1977). Pasture mowing or a general decrease in succulence of herbaceous hosts causes a dispersal of the adults that may settle in high numbers plants such as grapevine, olive, peach, almond, besides several trees and shrubs as holm oak, myrtle and lentisk (Goidanich 1954; Pavan 2006; Cornara et al. 2016b). For a $P$. spumarius complete host list, refer to Delong and Severin (1950) and Weaver and King (1954).

\section{Biology and ecology}

\section{Life history and behavior}

Philaenus spumarius is a univoltine species, overwintering as egg. First mature eggs are found in the ovaries starting from the end of August and then increase until November
(Weaver 1951). This delayed egg maturation is due to an ovarian parapause described by Witsack (1973). Females are polyandrous; the multiple mating does not influence the number of progeny, but provide great genetic and evolutionary benefits to the meadow spittlebug, as shown in many polyandrous species (Smith 1984). Yurtsever (2000) hypothesized that $P$. spumarius, very diverse habitats, is a consequence of the advantages derived from multiple mating. Mating occurs readily after adult appearance and continues throughout the seasons; the spermatogenesis and release of sperma in the spermatheca are designed so that delayed fertilization could take place (Robertson and Gibbs 1937). Weaver and King (1954) observed a peak of development for eggs not occurring until 2nd week of September, with no significant difference due to geographical location. The failure in spittlebug control with treatments in the first week of September is a further evidence that oviposition takes place after this period (King 1952). In Apulia, oviposition was achieved in semi-artificial conditions in October on Sorghum halepense L., concomitantly with a decrease in average daily temperature below ca. $15^{\circ} \mathrm{C}$; furthermore, the only eggs observed in the field were laid on the same plant along the orchard edges (Cornara and Porcelli 2014, Fig. 1). Eggs are oviposited in stubble, herbs, dead parts of plants, plant residue, cracks and tree trunk barks, or in the litter; the majority of eggs are laid close to the ground between two apposed surfaces (Barber and Ellis 1922; Weaver and King 1954; Yurtsever 2000). Furthermore, Weaver and King (1954) reported that the presence of straw within experimental cages caused an increase of $65 \%$ in egg deposition. Oat, Johnson grass, dwarf broad bean, alfalfa, red clover and timothy were reported as experimental hosts for oviposition (Weaver and King 1954; Halkka et al. 1966; Stewart and Lees 1988; Cornara and Porcelli 2014). Eggs are elongated, ovoid and tapering in shape, yellowish white with a dark pigmented orange spot at one end. If the egg is fertilized, the orange spot gets bigger and a black lid-like formation develops on it (Yurtsever 2000). Eggs are laid in masses of one to 30 elements, with an average value of seven, held together by a hardened frothy cement (Weaver and King 1954; Ossiannilsson 1981). Mundinger (1946) and Weaver and King (1954) agreed upon the number of eggs oviposited being around 18-51 per female, although a lower estimate, about 10-20 per female, was reported by Wiegert (1964). On the contrary, Yurtsever (2000) claims that an individual female may produce up to 350-400 eggs. These conflicting data suggest that experiments under controlled conditions aimed at estimating prolificacy are needed to estimate this important biological parameter. The oviposition continues until the female dies naturally or is killed by severe frost (Weaver and King 1954). The pre-imago passes through five instars. Pre-imaginal development takes 5-6 weeks, although cold weather considerably reduces the speed of 
Fig. 1 Biological cycle of Philaenus spumarius in Southern Apulia region of Italy. Photos by A. Fereres and D. Cornara
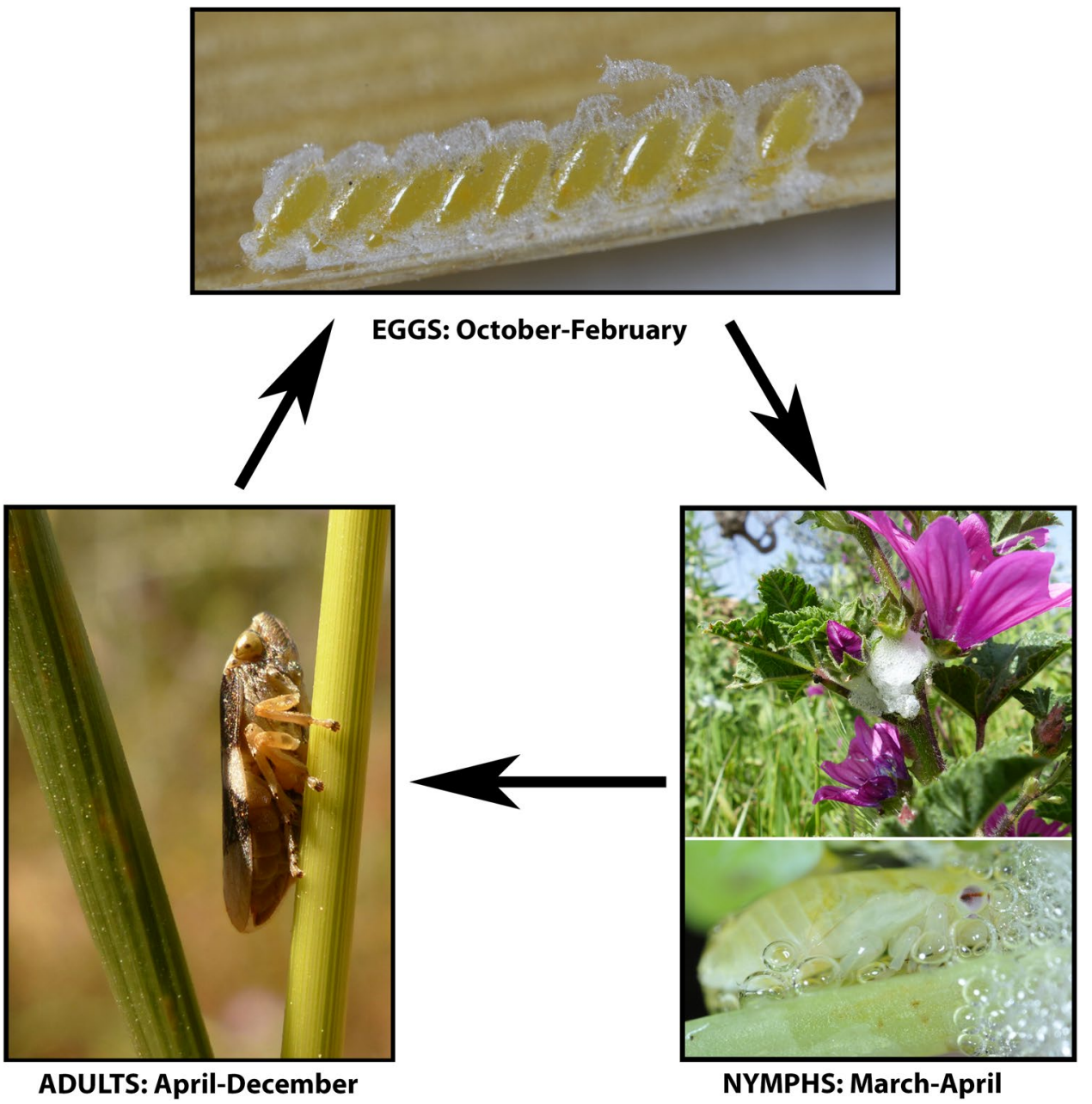

the cycle; consequently, nymphal period may take from 35 to 100 days approximately (Weaver and King 1954; Yurtsever 2000; Halkka et al. 2006). The first instar nymph is approximately $1.35 \mathrm{~mm}$ long, orange, and produces a tenuous spittle. During the development, the color became gradually greenish yellow; the last two instars produce a great amount of spittle (Yurtsever 2000). Once hatched, nymphs crawl to the closest green succulent plant and began forming a spittle (Weaver and King 1954). Selection of a feeding site on a plant may occur after the insect has ingested and sampled xylem sap (Horsfield 1977). The first nymphs can be found on low rosetting plants or in plants that offer closely apposed leaf and stem surfaces; these hosts indeed provide a shelter from direct sun and drying winds (Weaver and King 1954; Grant et al. 1998). Apparently, the nymph is able to survive on almost any plant that provides them with sufficient moisture to maintain their feeding habits (Weaver and King 1954). Plant mechanical defenses, as trichomes present on the stem of plants as Anaphalis margaritacea Benth \& Hook (1873), or tissue hardness, may inhibit young nymphs from feeding, mechanically impeding stylet penetration (Hoffman and McEvoy 1985a, b). The range of feeding sites exploited increases with nymphal development (Hoffman and McEvoy 1985a). Wiegert (1964) observed peak densities of 1280 nymphs $/ \mathrm{m}^{2}$ and 466 adults $/ \mathrm{m}^{2}$ in an alfalfa field. In Europe, nymphs' density has been reported not exceeding 1000 nymphs $/ \mathrm{m}^{2}$ (Zajac and Wilson 1984). Nymphs tend to aggregate on the host plants, sharing the same spittle. The aggregation, maintained within certain levels in order to avoid competition, ensures a bottom-up effect, for example, overcoming physical barriers to feeding on xylem (Wise et al. 2006). Individuals of different cercopid species may be found embedded in the same spittle mass (Halkka et al. 1977). As reported by Whittaker (1973), nymphs' mortality is inversely density dependent, whereas in adults a slight although significant density-dependent regulation exists. The same author found that, when $P$. spumarius is present in the field concomitantly with other spittlebug species as Neophilaenus lineatus L. (1758), both of the populations tend to be more stable.

After the spittle is formed, the nymph is able to maintain its own microclimate; evaporation rate gradients ensure that spittles are largest close to the ground, where they are most available to non-flying predators, and greater 
insulation from high temperature is required (Whittaker 1970). The same author also inferred that the spittle is a form of protection from predators. At the time of the last molt, the nymph ceases to form the spittle, which progressively dries up, forming a chamber where the adult stage will appear (Weaver and King 1954). Adults appear in April and live until fall (Weaver and King 1954), although they may survive throughout the successive spring in case of mild winters (Saponari et al. 2014). The callow adult is nearly white with a slight greenish cast; it takes some minutes to acquire its characteristic colored pattern (Weaver and King 1954). Industrial melanism for $P$. spumarius has been suggested (Lees and Dent 1983). Thompson (1973) claimed that $P$. spumarius color pattern warns the predator about the insect's exceptional escape ability through leaping. Therefore, a learned predator tends to avoid the meadow spittlebug because it associates the color pattern to a wasted effort in preying, due to the strong and rapid leaping of the prey (Gibson 1974). Males appear earlier than females, and, over the year, the number of males declines in comparison with females (Edwards 1935; Halkka 1964; Drosopoulos and Asche 1991).

\section{Phenology, developmental thresholds and temperature-dependent development}

Difficulties faced by researchers for decades in rearing $P$. spumarius continuously in the laboratory strongly suggests that the entire life cycle relies on a specific combination of environmental variables still not fully understood. A deep knowledge about phenology and developmental threshold is mandatory in order to set up an effective forecasting model for $P$. spumarius control. Two are the key factors regulating $P$. spumarius development: humidity and temperature.

According to Weaver and King (1954), several evidences, such as the behavior of nymphs seeking sheltered places, the production of foam and the necessary structure to produce it, the adult migration during the summer period, the delay until cool weather for the deposition of the eggs, the manner of placing and cementing the eggs between two apposed surfaces so that water losses are minimized, suggest that the entire life cycle depends on humidity and water availability. Even a cornea thicker in the adults compared to the nymph, which reduces water losses, might be considered a further evidence of the fact that water represents the key element around which the meadow spittlebug biology spins (Keskinen and Meyer-Rochow 2004). Weaver and King (1954) stated that the highest concentration of spittlebugs is contained within the regions of highest humidity. Humidity likely elicits hatching. Indeed, if eggs hatch in a high humidity environment, first instar nymph would survive to dehydration and could find a suitable tissue to settle on. The first plants on which nymphs are observed are those exhibiting dense lateral growth, thus limiting air movements and having a higher RH (relative humidity). Furthermore, nymphs tend to congregate on closely apposed surfaces where the humidity can be maintained at high levels, as noticed both in field and laboratory conditions using Sonchus sp. L. as a rearing plant (Morente et al. unpublished). As reported by Weaver and King (1954), early in the morning nymphs can be found at the tip of the plant, but as the temperature rises, the masses dry and they leave them to move down on the plant. The foam secreted by nymphs creates an excellent protection against dehydration and UV radiation. Indeed, $P$. spumarius foam case can block as much as $88 \%$ of the UV incident radiation (in the $250-400 \mathrm{~nm}$ range) (Chen et al. 2017). In spite of the indications on P. spumarius preference for moist environments, other reports point out that the meadow spittlebug colonizes nearly all habitats including wet or dry meadows and dry mediterranean forests (Guglielmino et al. 2005). Consistently, P. spumarius can be very abundant on herbaceous vegetation within and surrounding olive groves in the Apulia region of Italy, as well as in vineyards (Nicoli Aldini et al. 1998; Braccini and Pavan 2000; Pavan 2006). Olive and grapevine are rain fed Mediterranean crops that grow in dry environments. Thus, it can be concluded that $P$. spumarius has the potential to live under different environmental conditions, from moist to relatively dry, as long as the host plants are actively growing and not subjected to severe water stress. Due to the exceptionally wide area of distribution of this species, it cannot be excluded that the spittlebug requirement for humidity depends upon the geographical area the population lives in, or that different populations within the species have different humidity requirements.

Along the years, several authors have tried to establish correlations between the meadow spittlebug development and temperature. According to Medler (1955), eggs hatch after an accumulation of 150 degree days (DD), with a maximum daily accumulation of 10 degrees over ca. $4.4^{\circ} \mathrm{C}$. King (1952) failed to speed up egg development by decreasing temperature to $10{ }^{\circ} \mathrm{C}$ and diminishing day length to $13 \mathrm{~h} /$ day. Stewart and Lees (1988) succeeded in achieving oviposition in laboratory conditions, exposing eggs to $10{ }^{\circ} \mathrm{C}$ for 75-100 days, photoperiod 12/12 light/dark, 100\% HR and then increasing the temperature up to $15{ }^{\circ} \mathrm{C}$ until hatching occurred. Chmiel and Wilson (1979) stated that the 1st hatch can be predicted using an accumulation of $120 \mathrm{HU}$ (heating units calculated based on a threshold temperature of $6.5^{\circ} \mathrm{C}$ from the 1 st of January). Weaver and King (1954) hypothesized that hatching occurs at temperatures of ca. $10-21{ }^{\circ} \mathrm{C}$ and that cold temperatures may have a conditioning effect that speeds up eggs development. Nevertheless, the same authors reported that eggs never exposed to less than ca. $15{ }^{\circ} \mathrm{C}$ were able to hatch early in February. Masters et al. (1998) reported that milder winters resulted in an 
early hatching, with no significant effect on nymphal development. Weaver and King (1954) stated that in areas where the spring weather is variable and short cold periods are interspersed with warm periods, the hatching may be prolonged over a long period. According to Zajac et al. (1989), upper and lower thresholds for nymphal development are 2.8 and $26.7^{\circ} \mathrm{C}$, respectively. The first through the fifth instar nymphs and adults began appearing in the field at 2, 154, $262,364,472$ and $660 \mathrm{HU}$, respectively, as calculated from the first eggs hatching. The mean residence time of the five instars had been calculated in 154, 103, 101, 113 and 181 HUs, respectively (Zajac et al. 1989). All these information, often based on substantially different estimations of the lower temperature thresholds, reveals that no clear and consistent data on the influence of temperature on spittlebug development are available and new studies are needed to fill the gap.

Manipulation of the life cycle under controlled conditions in order to obtain more than one generation per year, thus extending the period for biological investigations of this species, does not seem an easy task, especially if we consider that termination of egg diapause requires a prolonged period of low temperatures, from 83 to 100 days (West and Lees 1988; Yurtsever, 2000). Also, experimental data on the viability of eggs stored at low temperature for several months in order to obtain nymphs later in the season are lacking. This represents a constraint in the studies of biology and behavior of $P$. spumarius under controlled conditions because the experiments need to be carried out in a limited period of the year when nymphs or adults are available.

\section{Movement}

Although the nymphs live inside a spittle, they can actively crawl on short distances, thus moving from one herbaceous plant to another, as observed by Bodino et al. (2017). Adults are much more mobile, both actively and passively. They can fly but, more often, they crawl or leap (Ossiannilsson 1981). Hind legs, usually dragged while walking, are the structures underlying the $P$. spumarius amazing jumping ability. Power muscles contracting slowly and storing energy, plus a peculiar joint interlocking mechanism, allow the insect to generate a force of 414 times its body weight, with a jump acceleration of $2800-4000 \mathrm{~m} / \mathrm{s}^{2}$ (Burrows 2003). A migratory behavior has been observed by several authors, with females migrating further and more readily than males (Weaver 1951; Weaver and King 1954; Lavigne 1959; Halkka 1962; Wiegert 1964; Halkka et al. 1967; Drosopoulos and Asche 1991; Grant et al. 1998). P. spumarius active dispersal is probably made possible by its high polyphagy (Halkka et al. 1967). The meadow spittlebug distribution largely depends on the distribution of suitable host plants, which often occur aggregated and frequently form a discrete pattern (Biedermann 2002). First dispersal is likely to happen when the adults are still tender and immature and can be related to harvest of the host crop or to a general decline in succulence of the host plant (Weaver and King 1954; Waloff 1973). Luxuriant foliage of newly seeded plants gradually but constantly attracts the spittlebug from the surroundings (Weaver 1951). The dissemination of the adults from the meadow is concomitant with an increase in population in other crops (Putman 1953). Migration continues until September, when adults gradually lessen their migratory activity. The diminishing of this tendency could be associated both with cooler temperatures and with the fact that females devote their energy to oviposition (Weaver and King 1954). An indirect evidence of the migration behavior is also provided by Drosopoulos and Asche (1991), which suggests the presence of a bivoltine $P$. spumarius population in Greece, with two peaks in adults collection, in May and October. Since the author did not find nymphs during summer, it can be speculated that the two peaks coincide with the migrations driven by loss of succulence in host plants and oviposition. The same author also observed a drastic reduction in population densities likely caused by spring and summer drought, with $P$. spumarius becoming a rare species in some years. Weaver and King (1954) observed marked $P$. spumarius traveling more than $30 \mathrm{~m}$ with a single flight and moving as much as $100 \mathrm{~m}$ within $24 \mathrm{~h}$ from the release point. The same authors stated that the spittlebug may hop for several feet but are poorly balanced, so that they land on their back. Adults mainly move at a height of $15-70 \mathrm{~cm}$ from the ground; higher movements seem unlikely, although observations of adults flying up to $6 \mathrm{~m}$ high are reported (Weaver and King 1954; Wilson and Shade 1967; Halkka et al. 1971). However, according to Freeman (1945), adults of $P$. spumarius can actually fly much higher than data reported by other authors. Indeed, Freeman collected one individual of $P$. spumarius and eight individuals of Neophilaenus lineatus with nets located $84 \mathrm{~m}$ above ground in the area of Lincolnshire (UK). Although in the mentioned paper the author reported these specimens generically as Cercopidae, actually it refers to $N$. lineatus and P. spumarius (Don Reynolds, personal communication). Such information suggests that $P$. spumarius can be transported by wind currents and is potentially capable of long-distance migration. Passive dispersal over great distances is mediated by wind and human activities (Weaver and King 1954). Dispersal power is sufficient to colonize all the microhabitats within an island and to reach nearby islands (Halkka et al. 1971; Schulz and Meijer 1978). Passive dispersal due to transportation by cars has been observed (Bosco, personal observation). A seasonal movement of adults from the herbaceous vegetation of olive groves to the olive canopy and other evergreen and deciduous trees/shrubs on late spring-early summer has been observed in Northern and Southern Italy (Cornara et al. 
2016b; Bodino et al. 2017). This movement is likely not only due to drying of the herbaceous hosts, as it can be observed even where the grass cover persists over the summer. An opposite movement occurs at the end of summer-beginning of autumn when adults, mostly females, re-colonize herbaceous vegetation looking for suitable sites of oviposition.

\section{Direct damage}

The meadow spittlebug began to receive attention during the 1940s, as a consequence of the built-up of large population and large infestations in meadow crop in the USA. As reported by Weaver and King (1954), during the late 1940s in Ohio approximately every legume hay field was heavily infested, with the complete loss of the first hay cutting. Moreover, the species has been regarded as a pest of strawberry (Mundinger 1946; Zajac and Wilson 1984). Outside the USA, $P$. spumarius had never been considered a pest. Direct damages by adult meadow spittlebugs seem unlikely, especially in view of the large number of adults congregating on a crop (Weaver and King 1954). On the contrary, losses associated with large infestation by nymphs on alfalfa, red clover, carrot, peas and strawberries in areas where $P$. spumarius was an alien pest have been reported in the USA, with nymphal feeding causing mainly dwarfing (Fisher and Allen 1946; Scholl and Medler 1947; Poos 1953; Weaver and King 1954). No effects of the spittlebug feeding on white clover (Trifolium repens) seed production were observed (Pearson 1991).

\section{Philaenus spumarius as a vector of plant pathogens}

While direct damages seem unlikely, transmission of plant pathogens represents the most serious threat posed by the meadow spittlebug to agriculture and landscape. $P$. spumarius has been erroneously reported as vector of the peach yellow virus, while further tests disproved its involvement in pathogen transmission (Severin 1950). Phytoplasmas have been detected in $P$. spumarius by several authors (Pavan 2000; Landi et al. 2007; Ivanauskas et al. 2014), and in one case the species was claimed to be a vector of ash yellow phytoplasmas (Matteoni and Sinclair 1988). However, this latter finding was not confirmed by further works (Sinclair and Griffiths 1994; Hill and Sinclair 2000) so that P. spumarius cannot be considered a vector of phytoplasmas until new convincing evidences are provided. Moreover, the spittlebug has been reported as a passive carrier of the plum mite (Mundinger 1946). P. spumarius was first reported as a vector of the bacterium Xylella fastidiosa Wells (1987) by Severin (1950). The ability of the meadow spittlebug in transmitting the bacterium was confirmed by further research, although it was suggested that this insect might play only a marginal role in X. fastidiosa epidemiology in the American outbreaks (Purcell 1980; Almeida et al. 2005; Sanderlin and Melanson 2010). It was not until 2014 that $P$. spumarius became a serious threat to European agriculture, when it was reported as the major vector of $X$. fastidiosa in the Apulia region, Southern Italy (Saponari et al. 2014; Cornara et al. 2016b).

\section{Role of $P$. spumarius in the first outbreak of $X$. fastidiosa in Europe, and remarks on other potential vectors}

Xylella fastidiosa establishment in Europe is a clear example of the consequences related to pathogen introduction and emergence in a new environment, where the pathogen itself finds a suitable vector able to drive disease epidemics (Almeida and Nunney 2015; Fereres 2015; Martelli et al. 2016). X. fastidiosa is a gram-negative xylem-limited gamma-proteobacterium, order Xanthomonadales, family Xanthomonadaceae, present throughout America. It causes diseases in many crops of economic importance such as grapevine, citrus, almond and others (Purcell 1997). According to EFSA (2015), its host list embraces 309 plant species belonging to 63 families. In Europe, the first establishment of the bacterium was reported by Saponari et al. (2013) on olive plants in Apulia showing severe symptoms of leaf scorch and dieback. This first detection was followed by findings of several subspecies and strains of X. fastidiosa in Corsica, mainland France, Germany and Spain (Denance et al. 2017; Olmo et al. 2017). The introduction is supposed to be related with trade of infected plant materials (Loconsole et al. 2016; Giampetruzzi et al. 2017). X. fastidiosa is transmitted exclusively by xylem sap-sucking insects (Frazier 1965). All the members of superfamilies Cercopoidea (commonly known as froghoppers or spittlebugs), Cicadoidea, and the subfamily Cicadellinae within the family Cicadellidae (also known as sharpshooters), are considered as xylem sap feeders (Novotny and Wilson 1997). Epidemiological data suggestive of an insect involvement in pathogen spread in USA, resulted in the identification of sharpshooters as vectors of $X$. fastidiosa to grapevine (Hewitt et al. 1942; Frazier and Freitag 1946). Thereafter, Severin (1950) discovered that, besides sharpshooters, also spittlebugs (Hemiptera: Aphrophoridae) were able to transmit the bacterium. Nevertheless, the epidemiological relevance of spittlebugs seems negligible in the Americans outbreaks. Almeida et al. (2005) suggests that spittlebugs might maintain the inoculum in pastures surrounding diseased vineyard. On the contrary, spittlebugs seem to play an important role in pecan leaf scorch in Louisiana (Sanderlin and Melanson, 2010). Furthermore, cicadas have been claimed to transmit the bacterium, although only two reports with limited datasets are available, and the level of uncertainties about cicadas role as vectors is currently very high 
(Paião et al. 2002; Krell et al. 2007; EFSA 2015). Overall, the amount of data about $X$. fastidiosa transmission by and interaction with sharpshooters is much larger than the whole background about spittlebugs and cicadas. Noteworthy, in Europe, only nine sharpshooter species are present (Fauna Europaea 2016), and few of them are common and abundant. Conversely, the widespread candidate vectors of $X$. fastidi$o s a$ in Europe seem to be spittlebugs (or froghoppers) and, possibly, cicadas (EFSA 2015).

The first vector survey during 2013 in Apulia, and successive transmission tests on periwinkle and olive plants, led to the identification of $P$. spumarius as vector of $X$. fastidiosa within the first European bacterium outbreak (Saponari et al. 2014). During the first tests carried out in October-November 2013 , $P$. spumarius transmitted the bacterium only to periwinkle plants but not to olive (Saponari et al. 2014). The role of $P$. spumarius in the transmission of the fastidious bacterium from olive to olive was proven by successive tests carried out during June-July 2014 (Cornara et al. 2016b). Furthermore, during 2014 it was observed that adults emerged in spring on ground cover within olive orchards tested negative to $X$. fastidiosa by qPCR. First positive individuals of 2014 were collected from infected olive canopies, with a great population colonizing this host approximately from sprouting to fruit setting (Cornara et al. 2016b, Fig. 2). These elements, although not entirely conclusive, strongly suggest: (1) the role of olive plants as the main bacterium reservoir within the olive orchard; (2) the implication of $P$. spumarius as the main species involved in the secondary spread of $X$. fastidiosa from olive to olive. $P$. spumarius movements within the olive orchard are still unclear: If the spittlebug follows the general rules for xylem sap feeders, movement would be influenced by plants physiology and biochemistry, with $P$. spumarius moving from plant to plant according to daily fluctuation of nutrient elements into the xylem sap (Andersen et al. 1992). Another important factor influencing spittlebugs movement is humidity (as previously discussed). During summer, when ground cover dries up and temperature dramatically increases, the spittlebugs find a perfect shelter in the olive canopies, where they can acquire the bacterium. After $X$. fastidiosa acquisition, $P$. spumarius would play an important role either in secondary transmission within the olive orchards, or in primary transmission to plants surrounding the orchard or several kilometers apart. Short-range bacterial dispersal after acquisition seems to rely on active spittlebug movements, whereas anthropogenic factors may have played a major role in long-range dispersal of infective individuals in Apulia. This theory is consistent with the spotted distribution of the outbreaks within Lecce Province (Martelli et al. 2016). Sumatra clove disease, caused by Pseudomonas syzigii, transmitted by Machaerotidae, sister taxon of Aphrophoridae, shows an analogous pattern, with sources of primary spread several kilometers far from new hotspots (Eden-Green et al. 1992). Furthermore, the large number of
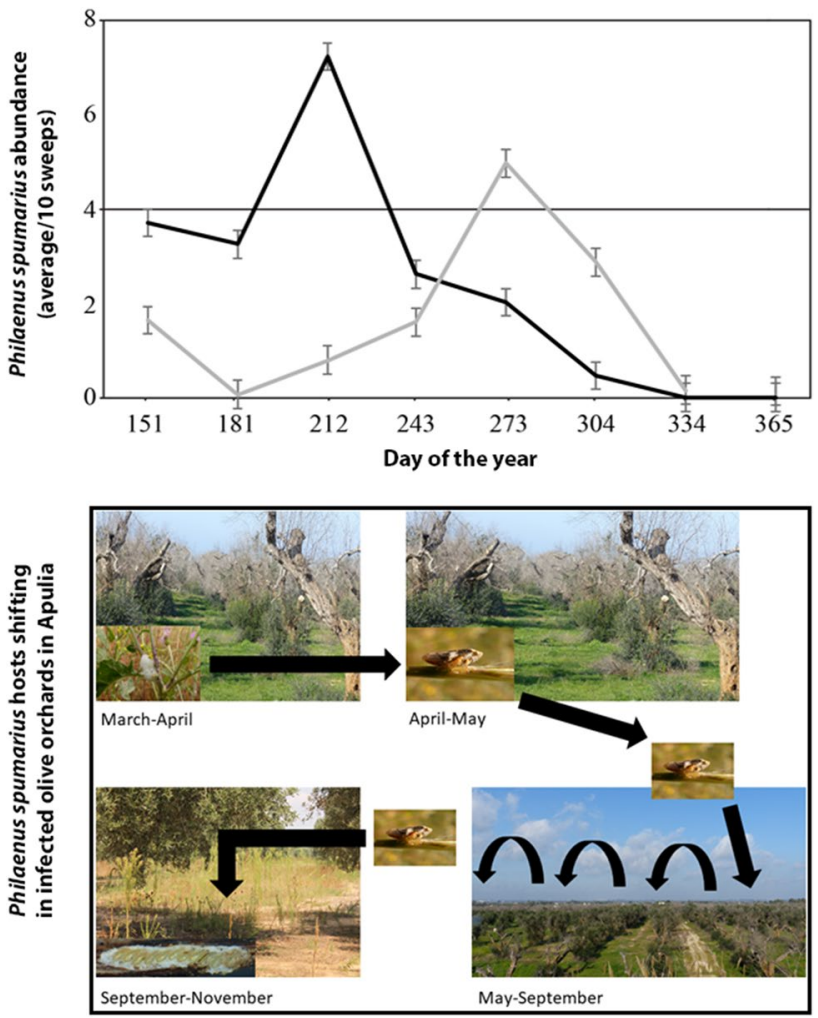

Fig. 2 Philaenus spumarius abundance on olive and ground cover during the year, and hosts shifting in infected olive orchards in Apulia (South Italy). Black line refers to $P$. spumarius adults abundance on olive plants; gray line refers to ground cover. Figure elaborated from Cornara et al. (2016b)

spittlebugs present within the olive canopy for several weeks/ months may dramatically increase the probability of infection and reduce the disease incubation period (Daugherty and Almeida 2009). According to Purcell (1981), the probability of a plant being infected with $X$. fastidiosa is directly proportional to four factors: vector infectivity (i), transmission efficiency (E), number of vectors (n) and time they spent on the host (t). As shown by Daugherty and Almeida (2009), i and E are proportional to $\mathrm{n}$ and $\mathrm{t}$ : Practically speaking, even if the vector is relatively inefficient, the infection is inevitable when large population settles on the host plant for long time. Incubation time on olive is still unknown: Saponari et al. (2016) stated that symptoms appear 12-14 months after artificial inoculation on young olive plants in greenhouse conditions. Nevertheless, incubation period in the field may differ from laboratory results, mainly because of the different age of the plants and their previous and concomitant exposition to biotic and abiotic stresses and number of inoculation events. Regarding $P$. spumarius transmission efficiency, Cornara et al. (2016c) estimated the daily value in ca. $20 \%$ using as a proxy grapevine plants and $X$. fastidiosa subsp. fastidiosa strain STL. Within grapevine, $X$. fastidiosa reaches very high population, likely 100-1000 times greater than in olive (Saponari et al. 
2016): Taking into account that the main factor influencing transmission is bacterial population present within the source plant (Hill and Purcell 1997), P. spumarius transmission efficiency to olive could be lower than the value reported for grapevine. Altogether, data gathered from transmission experiments with grapevine showed that $X$. fastidiosa transmission by $P$. spumarius does not differ from the dynamics reported for sharpshooters. Nevertheless, whereas several authors reported no correlation between bacterial population in the vector foregut and pathogen transmission (Hill and Purcell 1995; Almeida and Purcell 2003; Rashed et al. 2011), Cornara et al. (2016c) showed that for P. spumarius this correlation exists. Moreover, either in the experiment with grapevine carried out with Californian population of the spittlebug, or analyzing insects collected from infected olive canopies in Apulia, the bacterial population found within the insect was ten to one hundred times lower than that reported for sharpshooters (Cornara et al. 2016a, c). Thus, despite similarities in overall transmission dynamic, $P$. spumarius showed two novel unexplored characteristics in relation to better studied sharpshooters: The insect hosts a relatively low population of bacterial cells, around 100-1000 cells for individual; moreover, the extent of the population is directly correlated with transmission efficiency. Furthermore, Killiny and Almeida (2009) reported that, once acquired, $X$. fastidios $a$ starts to multiply at a constant rate within the foregut, saturating the available space in ca. 7 days, reaching a population of 10,000-50,000 cells/insect. Quantitative PCR analyses of the individuals used for transmission experiment on grapevine revealed that the bacterium within the foregut of $P$. spumarius reaches the population peak of ca. 1000 cells/insect in less than three days (Cornara et al. 2016c). Cornara et al. (2016c) hypothesized two possible explanations underlying the observed phenomenon: The first relies on cuticle chemistry and potential bacterial receptors within the foregut; the second is related to insect probing behavior. During acquisition, $X$. fastidiosa adhesins bind to insect cuticle, likely on the part of the precibarium proximal to cibarium (Almeida and Purcell 2006; Killiny and Almeida 2009); chitin, the main cuticle polysaccharide, is used by the bacterial cells as a carbon source (Killiny et al. 2010). P. spumarius foregut may host few bacterial cells because of differences in the availability of polysaccharides or sites where the first binding or the successive multiplication takes place. Alternatively or concomitantly, the observed difference may be related to $P$. spumarius probing behavior: The meadow spittlebug has been demonstrated to feed on the main xylem stream, where tremendous tension even greater than -10 bars occurs (Malone et al. 1999). To feed on xylem mainstream, $P$. spumarius has to overcome this tension, loading the cibarial muscles until balancing vessel negative pressure. As shown with sharpshooters, the cibarial pump performs one up-anddown movement every second, and the fluid flows within the foregut very rapidly (Purcell et al. 1979; Dugravot et al. 2008).
Under these conditions, bacterial cells binding should not be straightforward, but the feeding behavior of $P$. spumarius may make either binding or multiplication even more challenging. Electrical penetration graph (EPG) is a technology devised by McLean and Kinsey in 1964, then improved by Tjallingii in 1978 , and to date considered an essential tool in research on probing behavior and pathogen transmission by piercing-sucking insects (Walker 2000). A detailed EPG-assisted study of $P$. spumarius probing behavior in relation to $X$. fastidiosa transmission may shed the light on this phenomenon, providing useful data for blocking pathogen transmission, following the approach illustrated by Killiny et al. (2012) and Labroussaa et al. (2016).

Besides olive, Cornara et al. (2016a) showed that P. spumarius transmits $X$. fastidiosa pauca ST53 to several host plants, namely oleander, periwinkle, the stone fruit rootstock GF677 and sweet orange, but not grapevines. For transmission tests, groups of five insects per plant were used; as expected, the number of infective spittlebugs was directly correlated with transmission probability. The same authors reported that systemic colonization does not take place neither in GF677 nor in sweet orange, consistently with bacterial artificial inoculation data reported by Saponari et al. (2016). Furthermore, X. fastidiosa was never detected in hundreds of Citrus spp. plants monitored within the infected area (Martelli et al. 2016). Eventually, the above-reported findings demonstrate the main role of $P$. spumarius as vector of $X$. fastidiosa in the Apulian outbreak. Besides the meadow spittlebug, three other xylem "specialist" feeders have been found in surveyed Apulia olive orchards: $N$. campestris, Cercopis sanguinolenta Scopoli (1763), Cicada orni L. (1758) (Cornara et al. 2016b). Whereas either $N$. campestris or $C$. sanguinolenta seem not to play a significant role in the transmission of $X$. fastidiosa to olive, the impact of these species as vector of the bacterium should be investigated on other host plants and agro-ecosystems (Cornara et al. 2016b). Regarding C. orni, in a recent natural infectivity test Cornara et al. (unpublished) found three out of 160 cicadas positive to $X$. fastidiosa by qPCR, while no transmission to olive recipient plants occurred. Eventually, more research efforts are needed in order to understand the epidemiological relevance of either $P$. spumarius or other candidate vectors in agro-ecosystems different from olive orchards, and across other European epidemics.

\section{Control: integrated pest management and sustainable control perspectives}

Integrated pest management strongly relies on effective sampling and surveillance methods. Unfortunately, to date, an effective method for $P$. spumarius sampling is still missing. Sweep net is the most common method used for adult collection; however, as remarked by Purcell et al. (1994), sweep 
net is a poorly effective tool for sampling insects from a tree canopy, in contrast with its high efficacy on the ground cover. Although sweep net is the tool largely used to collect $P$. spumarius, other methods, namely minicage (biocenometers), pitfall traps, sticky traps, aerial suction traps, beat tray and tanglefoot bands, have been tested. However, all these methods were proven to be less effective than sweep net (Weaver and King 1954; Lavigne 1959; Wilson and Shade 1967; Novotny 1992; Pavan 2000; Bleicher et al. 2010). To the best of our knowledge, only one study focused on effectiveness of different color sticky traps in collecting the meadow spittlebug has been performed, with yellow resulting more attractive than green, red, pink, blue and white (Wilson and Shade 1967). Nevertheless, preliminary results of observations conducted in Apulia and Spain suggests the low efficacy of yellow sticky traps in $P$. spumarius collection and other colors need to be tested (Morente et al., unpublished data). Researches carried out on vibrational signals produced by Homalodisca vitripennis Germar (1821) opened new and interesting perspectives for the control of this $X$. fastidiosa vector in US vineyard (Nieri et al. 2017). The occurrence of communication through vibrations should be explored also for P. spumarius; the outcomes of such researches could open new venues in order to set up an effective monitoring tool. On the other hand, recent studies on the fine structure of antennal sensilla of the spittlebug allowed to identify chemoreceptors (Ranieri et al. 2016). Although the presence of olfactory receptors among the antenna is limited, it is possible that $P$. spumarius responds to olfactory attractants, e.g., plant attractants, thus providing new tools for monitoring and control. Unfortunately, so far pheromones have not been identified in spittlebugs, with the exception of an aggregation pheromone of the rice spittlebug Callitettix versicolor nymphs (Chen and Liang 2015), and therefore monitoring and control methods based on the use of pheromones are very unlikely to be developed for $P$. spumarius.

To date, considering that $X$. fastidiosa eradication is no more feasible and Apulia had become a reservoir of the bacterium, an effective disease management strategy is mandatory for the survival of agriculture and landscape (Strona et al. 2017). Strategies focused on disruption of only one single aspect of the complex interaction vector-plant-pathogen have proven many times to be unsuccessful (Almeida et al., 2005). X. fastidiosa provides one of the best examples of an arthropod-borne pathogen whose control strongly depends on several interacting variables: crop; agricultural practices; weather; vector biology, host range and behavior; pathogen host range; transmission mode, primary or secondary (Almeida et al. 2005). Therefore, management of $X$. fastidiosa epidemics should be based on a combination of multiple tactics that partially interrupt more than one interaction of the pathosystem (Almeida et al. 2005). At least in Salento olive orchards, available data strongly suggest that $P$. spumarius transmits $X$. fastidiosa from tree to tree, with olive being the primary source of the bacterium. In such case of "secondary transmission," the disease control strategy should be based on exclusion of the pathogen from propagative material, removal of infected plants, and vector control to reduce transmission within and between the orchards (Lopes and Krugner 2016). According to the funding theories of integrated pest management, an effective pest control strategy should target the most vulnerable stages of the insect life cycle, when the control tools can act on the residual pest population already affected by, or exposed to, biotic and abiotic factors (Lewis et al. 1997; Kogan 1998). Looking at $P$. spumarius life cycle and behavior, two are the weakest point on which control measures could achieve the best results: nymphal stage, and newly emerged noninfective adults shifting to olive plants. Nymphs develop in natural vegetation within and on the margins and hedgerows of olive groves during spring. Removal of ground cover hosting the nymphs either by mowing, soil tillage or herbicides within and surrounding olive orchards could be effective in drastically reducing resident vector population. Nevertheless, indiscriminate removal of ground cover could be ecologically deleterious, with large-scale environmental impact (Civitello et al. 2015). Another alternative approach could be represented by the use of physical or chemical compounds that remove and further affect the spittle production, since the ability of the nymph to survive out of the spittle is very limited. Chemical control of nymphs was not yet been extensively investigated so far, but could also reduce resident vector population in olive groves.

Adult control is mainly hampered by migration tendency that would soon balance the amount of adults dead after insecticides application. King (1952) observed that treatments in midsummer were ineffective in spittlebug control, since the population would be soon equalized by successive migration from surrounding habitats. $P$. spumarius adults control in olive orchards should be mainly focused on disrupting $X$. fastidiosa acquisition from olive plants that likely occur when non-infective recently molted adults migrate from ground cover to tender olive sprouts. Carefully planned insecticides application to olive and surrounding plants before adult shift to olive would expose twice the spittlebug to the pesticide: once before and when the insects alight on infected tree; secondly, when potentially infective vectors move to healthy trees (Almeida et al. 2005). Currently, very few reports on the activity of insecticides against $P$. spumarius are available, because before the $X$. fastidiosa European outbreak the species was not considered a pest and therefore was not targeted with insecticides. A recent experiment carried out in Apulia on insecticide control of adults on olive showed that the neonicotinoids acetamiprid and imidacloprid and pyrethroids deltamethrin and lambda-cyhalothrin displayed a high mortality rate. 
The insect growth regulators buprofezin and spirotetramat showed no acute lethal effect as well as the pyridine azomethine, pymetrozine. Among botanical insecticides, citrus oil showed a good insect mortality when applied at the volume of $2000 \mathrm{~L} / \mathrm{ha}$ (although its activity is not persistent at all), while no toxic effect was recorded using azadirachtin (Dongiovanni et al. 2016). Data on chronic effect or impact of the compounds in reducing $X$. fastidiosa transmission are still missing. Neonicotinoids were successfully used in Brazil against CVC vectors, through roots and soil application on less than 3-year-old citrus plant and by spraying on elder plants (Lopes and Krugner 2016). Nevertheless, treatments with imidacloprid proved to be ineffective in preventing grapevines infection with $X$. fastidiosa in areas with prevalent sources of inoculum and high vector abundance (Krewer et al. 2002). Besides the induced mortality, insecticides as neonicotinoids and repellent as the aluminum silicate kaolin could interfere with $X$. fastidios $a$-vector interaction by affecting vector orientation, host determination and feeding behavior, as shown in H. vitripennis (Tubajika et al. 2007). Kaolin particles, that protect the hosts against the vector by camouflaging the plant with a white coating, making them visually unperceivable, or by reflecting sunlight, might represent a valid control tool, especially for organic olive orchards (Puterka et al. 2003). The negative effect of spittlebug migration from the surroundings on the effectiveness of insecticides applications could be mitigated by coupling insecticide treatments with installation around the olive orchard of screen physical barriers that proved to be efficient in reducing GWSS population migrating from the surrounding citrus orchards into vineyards (Blua et al. 2005). Nevertheless, even if effective, the benefits coming from proper control strategies would result in just a "hold back the tide" strategy, if the measures will not be extended to the widest possible area.

The control of the meadow spittlebug with parasitoids and predators is still far from its application, and more research efforts are needed to find a suitable candidate to pursue this task. Indeed, detailed information about the meadow spittlebug natural enemies is still scattered and missing. Predation seems not to be an important source of mortality (Whittaker 1973). Birds, frogs, Arachnids Phalangiidae, Hymenoptera, Diptera and Coleoptera Carabidae, prey $P$. spumarius (Phillipson 1960; Halkka et al. 1976; Harper and Whittaker 1976; Henderson et al. 1990). Westwood in 1840 (cited by Weaver and King 1954), and more recently Pagliano and Alma (1997), observed Argogorytes mystaceus L. (1761) (Hymenoptera: Sphecidae) (Gorytes mystaceus in Westwood 1840) dragging $P$. spumarius nymphs from their spittle masses. Very recently, the Reduviidae bug Zelus renardii Kolenati has been proposed as a biological control agent in olive orchards of P. spumarius (Salerno et al., 2017). The dipteran parasitoid Verrallia aucta Fallen
(1817) (Diptera: Pipunculidae), found in Europe and Central Siberia, is responsible for adults sterility bringing them to death just in the last part of their cycle; parasitism rate is likely to be not greater than 1\% (Whittaker 1969, 1973; de Meyer and de Bruyn 1984; Van Driesche et al. 1987). Furthermore, the nematode Agamermis decaudata Cobb, Steiner \& Christie (1923), and the entomopathogenic fungi Entomophtora sp. Fresen (1856) attack the adults (Weaver and King 1954, Harper and Whittaker 1976; Ben-Ze'Ev and Kenneth 1981). Eggs are parasitized by Hymenoptera of the genus Ooctonus spp., Tumidiscapus sp., and Centrodora sp., which were found parasitizing around $10 \%$ of field-collected eggs in 1951 in Ohio (Weaver and King 1954).

Promising researches focused on disrupting $X$. fastidi$o s a$-vector interactions are ongoing. Deliver of lectins, carbohydrates and antibodies to a vector through artificial diet significantly impacted bacterial acquisition and subsequent transmission (Killiny et al. 2012). Furthermore, recombinant peptides efficiently blocked $X$. fastidiosa acquisition and initial bind to foregut, while they did not interfere with successive steps of bacterial multiplication once the bacterium had been acquired and was bound to the cuticle (Labroussaa et al. 2016). Nevertheless, such strategies, tested on sharpshooters, should be further assessed for $P$. spumarius, whose intimate relationship with the bacterium is different, to some extent, to the one of Cicadellinae (Cornara et al. 2016c). Moreover, deepening our knowledge about $P$. spumarius feeding behavior and $X$. fastidiosa transmission mechanism through a real-time observation device as EPG could open new venues in the discovery of an effective strategy to disrupt bacterium-spittlebug interaction.

\section{Concluding remarks}

- The meadow spittlebug $P$. spumarius, never considered a pest in Europe, raised the attention of scientists and stakeholders after the discovery of its main role in the transmission of $X$. fastidiosa strain ST53 to olive in the first reported European outbreak of the bacterium, occurred in Apulia (South Italy) in 2013.

- P. spumarius is widely distributed, covering most of the Palearctic region and extending to Nearctic. The spittlebug is highly polyphagous, occurring in most of the terrestrial habitats; furthermore, $P$. spumarius has the potential to live under different environmental conditions, from moist to relatively dry, as long as the host plants are actively growing, and not subjected to severe water stress.

- Lack of key information on P. spumarius urgently calls for research on aspects considered fundamental for developing effective pest management strategies: life history, ecology, phenology, population dynamics, movement and 
dispersal, tri-trophic relationships, host plant association and preference, reproductive biology, feeding behavior, vibrational communication, effect of plant volatiles on host search and recognition, insect microbiome, natural enemies.

- X. fastidiosa-associated disease control strategies should include measures aimed at (1) suppressing vector populations and (2) suppressing sources of inoculum for the vector. To achieve these goals, we should consider the ecology and population dynamics of $P$. spumarius in different sites and crop systems, as there are no universally applicable solutions. As for suppressing P. spumarius population, control strategies should target two stages of the insect life history: nymphs and newly emerged non-infective adults that can move toward X. fastidiosa source plants. Moreover, as soon as research will provide new insights on vector-plant-pathogen interactions, innovative control strategies should be developed with the aim of targeting different aspects of these interactions. Finally, control measures should be applied on the widest possible area.

- Eventually, the more we learn about the vector-bacterium-plant relationships, the faster we will find the way to cohabit with $X$. fastidiosa-associated diseases, reducing the impact of a bacterium that, to date, represents one of the most frightening threat to European agriculture and landscape.

\section{Author contributions}

DC, DB and AF collected the data and wrote the paper.

Acknowledgements Authors would like to acknowledge an EFSA procurement action on the information on biology and control of vectors of Xylella fastidiosa, the European Union Horizon 2020 research and innovation program under Grant Agreement No. 635646 POnTE (Pest Organisms Threatening Europe), and Grant Agreement No. 727987 XF-ACTORS.

\section{Compliance with ethical standards}

Conflict of interest The authors declare no conflicts of interest.

Human and animal rights statement This article does not contain any studies with human participants or animals performed by any of the authors.

\section{References}

Almeida RP, Nunney L (2015) How do plant diseases caused by Xylella fastidiosa emerge? Plant Dis 99:1457-1467
Almeida RPP, Purcell AH (2003) Homalodisca coagulata (Hemiptera, Cicadellidae) transmission of Xylella fastidiosa to almond. Plant Dis 87:1255-1259

Almeida RP, Purcell AH (2006) Patterns of Xylella fastidiosa colonization on the precibarium of sharpshooter vectors relative to transmission to plants. Ann Entomol Soc Am 99:884-890

Almeida RP, Blua MJ, Lopes JR, Purcell AH (2005) Vector transmission of Xylella fastidiosa: applying fundamental knowledge to generate disease management strategies. Ann Entomol Soc Am 98:775-786

Andersen PC, Brodbeck BV, Mizell RF (1992) Feeding by the leafhopper, Homalodisca coagulata, in relation to xylem fluid chemistry and tension. J Insect Physiol 38:611-622

Barber GW, Ellis WO (1922) Eggs of Tree Cercopidae. Psyche 29:1-3

Ben-Ze'ev I, Kenneth RG (1981) Zoophthora radicans and Zoophthora petchi sp. nov. [Zygomycetes: Entomophthorales], two species of the "Sphaerosperma group" attacking leaf-hoppers and froghoppers [Hom.]. Entomophaga 26:131-142

Berry AJ, Willmer PG (1986) Temperature and the colour polymorphism of Philaenus spumarius (Homoptera: Aphrophoridae). Ecol Entomol 11:251-259

Biedermann R (2002) Leafhoppers (Hemiptera, Auchenorrhyncha) in fragmented habitats. Denisia 176:523-530

Bleicher K, Orosz A, Cross J, Markó V (2010) Survey of leafhoppers, planthoppers and froghoppers (Auchenorrhyncha) in apple orchards in South-East England. Acta Phytopathol Hun 45:93-105

Blua MJ, Campbell K, Morgan DJW, Redak RA (2005) Impact of a screen barrier on dispersion behavior of Homalodisca coagulata (Hemiptera: Cicadellidae). J Econ Entomol 98:1664-1668

Bodino N, Plazio E, Cavalieri V, Dongiovanni E, Ripamonti M, Volani S, Gilioli G, Fumarola G, Di Carolo M, Porcelli F, Bosco D (2017) Host-plant association and host-shifting of nymphs and adults of Philaenus spumarius L. in Italian olive orchards. In: Proceedings 3rd Hemipteran-plant interactions symposium (HPIS), Madrid, Spain, 4-8 June 2017, p 36

Braccini P, Pavan F (2000) Auchenorryncha: potential vectors of phytoplasms associated with vine yellows. Informatore Agrario 56:103-107

Burrows M (2003) Biomechanics: froghopper insects leap to new heights. Nature 424:509

Chen X, Liang AP (2015) Identification of a self-regulatory pheromone system that controls nymph aggregation behavior of rice spittlebug Callitettix versicolor. Front Zool 12:1-12

Chen X, Meyer-Rochow VB, Fereres A, Morente A, Liang AP (2017) The role of biofoam in shielding spittlebug nymphs (Insecta, Hemiptera, Cercopidae) against bright light. Ecol Entomol. https ://doi.org/10.1111/een.12496

Chmiel SM, Wilson MC (1979) Estimation of the lower and upper developmental threshold temperatures and duration of the nymphal stages of the meadow spittlebug, Philaenus spumarius. Environ Entomol 8:682-685

Civitello DJ, Cohen J, Fatima H, Halstead NT, Liriano J, McMahon TA, Ortega CN, Sauer EL, Sehgal T, Young S (2015) Biodiversity inhibits parasites: broad evidence for the dilution effect. Proc Natl Acad Sci 112:8667-8671

Cornara D, Porcelli F (2014) Observations on the biology and ethology of Aphrophroridae: Philaenus spumarius in the Salento peninsula. In: Proceedings "International symposium on the European outbreak of Xylella fastidiosa in olive", Gallipoli-Locorotondo, Italy, 21-24 Oct 2014

Cornara D, Cavalieri V, Dongiovanni C, Altamura G, Palmisano F, Bosco D, Porcelli F, Almeida RP, Saponari M (2016a) Transmission of Xylella fastidiosa by naturally infected Philaenus spumarius (Hemiptera, Aphrophoridae) to different host plants. J Appl Entomol. https://doi.org/10.1111/jen.12365 
Cornara D, Saponari M, Zeilinger AR, de Stradis A, Boscia D, Loconsole G, Bosco D, Martelli GP, Almeida RPP, Porcelli F (2016b) Spittlebugs as vectors of Xylella fastidiosa in olive orchards in Italy. J Pest Sci. https://doi.org/10.1007/s10340-016-0793-0

Cornara D, Sicard A, Zeilinger AR, Porcelli F, Purcell AH, Almeida RPP (2016c) Transmission of Xylella fastidiosa to grapevine by the meadow spittlebug. Phytopathology 106:1285-1290

Crews L, McCully M, Canny M, Huang C, Ling L (1998) Xylem feeding by spittlebug nymphs: some observations by optical and cryo-scanning electron microscopy. Am J Bot 85:449-460

Daugherty MP, Almeida RPP (2009) Estimating Xylella fastidiosa transmission parameters: decoupling sharpshooter number and feeding period. Entomol Exp Appl 132:84-92

de Meyer M, de Bruyn L (1984) On the phenology of some Pipunculidae (Diptera) in Belgium. Bulletin et Annales de La Société Royale Belge D'entomologie 120:123-131

Delong DM, Severin HH (1950) Spittle-insect vectors of Pierce's disease virus. Hilgardia 19:339-376

Denance N, Legendre B, Briand M, Olivier V, de Boisseson C, Poliakoff F, Jacques MA (2017) Several subspecies and sequence types are associated with the emergence of Xylella fastidiosa in natural settings in France. Plant Pathol. https://doi.org/10.1111/ ppa.12695

Dongiovanni C, Cavalieri V, Altamura G, Di Carolo M, Fumarola G, Saponari M, Porcelli F (2016) Preliminary results of comparative efficacy evaluation trials against Philaenus spumarius L., vector of Xylella fastidiosa. Options Méditerranéennes, A No. 121, 2017-Xylella fastidiosa \& the Olive Quick Decline Syndrome (OQDS). A serious worldwide challenge for the safeguard of olive trees, pp 79-80

Drosopoulos S (2003) New data on the nature and origin of colour polymorphism in the spittlebug genus Philaenus (Hemiptera: Aphorophoridae). Ann Soc Entomol Fr 39:31-42

Drosopoulos S, Asche M (1991) Biosystematic studies on the spittlebug genus Philaenus with the description of a new species. Zool J Linn Soc 101:169-177

Drosopoulos S, Remane R (2000) Biogeographic studies on the spittlebug Philaenus signatus Melichar, 1896 species group (Hemiptera: Aphrophoridae) with the description of two new allopatric species. Ann Soc Entomol Fr 36:269-277

Dugravot S, Backus EA, Reardon BJ, Miller TA (2008) Correlations of cibarial muscle activities of Homalodisca spp. sharpshooters (Hemiptera: Cicadellidae) with EPG ingestion waveform and excretion. J Insect Physiol 54:1467-1478

Eden-Green S, Balfas R, Sutarjo T (1992) Characteristics of the transmission of Sumatra disease of cloves by tube-building cercopoids, Hindola spp. Plant Pathol 41:702-712

Edwards WD (1935) Strawberry pests including the spittlebug. Ann Rep Oregon State Hortic Soc 27:58-65

EFSA (2015) Scientific Opinion on the risk to plant health posed by Xylella fastidiosa in the EU territory, with the identification and evaluation of risk reduction options. EFSA J 13:3989

Fauna Europaea (2016) Museum für Naturkunde Leibniz-Institut für Evolutions- und Biodiversitätsforschung Invalidenstr. Berlin, Germany. https://fauna-eu.org/

Fereres A (2015) Insect vectors as drivers of plant virus emergence. Curr Opin Virol 10:42-46

Fisher EH, Allen TC (1946) Alfalfa and clover severely damaged by spittlebugs. What's new in farm science. Wis Agric Exp Stn Bull 469:15-16

Frazier NW (1965) Xylem viruses and their insect vectors. In: Proceedings of the international conference on virus and vectors on perennial hosts, with special reference to Vitis, pp 91-99

Frazier NW, Freitag JH (1946) 10 additional leafhopper vectors of the virus causing pierces disease of grapes. Phytopathology $36: 634-637$
Freeman JA (1945) Studies in the distribution of insects by aerial currents. J Anim Ecol 104:128-154

Giampetruzzi A, Saponari M, Loconsole G, Boscia D, Savino VN, Almeida RP, Zicca S, Landa BB, Chacón-Diaz C, Saldarelli P (2017) Genome-wide analysis provides evidence on the genetic relatedness of the emergent Xylella fastidiosa genotype in Italy to isolates from Central America. Phytopathology 107:816-827

Gibson DO (1974) Batesian mimicry without distastefulness? Nature 250:77-79

Goidanich A (1954) Enciclopedia Agraria Italiana. Roma, REDA

Grant JF, Lambdin PL, Follum RA (1998) Infestation levels and seasonal incidence of the meadow spittlebug (Homoptera: Cercopidae) on musk thistle in Tennessee. J Agric Entomol 15:83-91

Guglielmino A, Bückle C, Remane R (2005) Contribution to the knowledge of the Auchenorrhyncha fauna of Central Italy (Hemiptera, Fulgoromorpha et Cicadomorpha). Marburger Entomologische Publikationen 3(3):13-98

Gulijeva EM (1961) Pennitsa P. spumarius-vreditel' Zernovykh lul'tur v Azerbaidzhane. Izvest Akad Navk SSR Ser Biol I Med Nauk 5:73-81

Halkka O (1962) Equilibrium populations of Philaenus spumarius L. Nature 193:93-94

Halkka O (1964) Geographical, spatial and temporal variability in the balanced polymorphism of Philaenus spumarius. Heredity 19:383-401

Halkka O, Heinonen L, Raatikainen M, Vasarainen A (1966) Crossing experiments with Philaenus spumarius (Homoptera). Hereditas $56: 306-312$

Halkka O, Raatikainen M, Vasarainen A, Heinonen L (1967) Ecology and ecological genetics of Philaenus spumarius (L.)(Homoptera). Ann Zool Fenn 4:1-18

Halkka O, Raatikainen M, Halkka L, Lokki J (1971) Factors determining the size and composition of island populations of Philaenus spumarius (L.)(Homoptera). Acta Entomol Fenn 28:83-100

Halkka O, Kohila T, Komila T (1976) Persistence of visual polymorphism, despite a low rate of predation, in Philaenus spumarius (L.)(Homoptera, Aphrophoridae). Ann Zool Fenn 13:185-188

Halkka O, Raatikainen M, Halkka L, Raatikainen T (1977) Coexistence of four species of spittle-producing Homoptera. Ann Zool Fenn 14:228-231

Halkka A, Halkka L, Halkka O, Roukka K, Pokki J (2006) Lagged effects of North Atlantic Oscillation on spittlebug Philaenus spumarius (Homoptera) abundance and survival. Glob Change Biol 12:2250-2262

Harper G, Whittaker JB (1976) The role of natural enemies in the colour polymorphism of Philaenus spumarius (L.). J Anim Ecol 45:91-104

Henderson G, Hoffman GD, Jeanne RL (1990) Predation on cercopids and material use of the spittle in aphid-tent construction by prairie ants. Psyche 97:43-53

Hewitt WB, Frazier NW, Houston BR (1942) Transmission of Pierce's disease of grapevine with a leafhopper. Phytopathology 32:8

Hill B, Purcell AH (1995) Acquisition and retention of Xylella fastidiosa by an efficient vector, Graphocephala atropunctata. Phytopathology 85:209-212. https://doi.org/10.1094/Phyto-85-209

Hill BL, Purcell AH (1997) Populations of Xylella fastidiosa in plants required for transmission by an efficient vector. Phytopathology 87:1197-1201

Hill GT, Sinclair WA (2000) Taxa of leafhoppers carrying phytoplasmas at sites of ash yellows occurrence in New York State. Plant Dis 84:134-138

Hoffman G, Mcevoy PB (1985a) Mechanical limitations on feeding by meadow spittlebugs Philaenus spumarius (Homoptera: Cercopidae) on wild and cultivated host plants. Ecol Entomol $10: 415-426$ 
Hoffman GD, McEvoy PB (1985b) The mechanism of trichome resistance in Anaphalis margaritacea to the meadow spittlebug Philaenus spumarius. Entomol Exp Appl 39:123-129

Horsfield D (1977) Relationships between feeding of Philaenus spumarius (L.) and the amino acid concentration in the xylem sap. Ecol Entomol 2:259-266

Horsfield D (1978) Evidence for xylem feeding by Philaenus spumarius (L.)(Homoptera: Cercopidae). Entomol Exp Appl 24:95-99

Ivanauskas A, Valiūnas D, Jomantienė R, Picciau L, Davis RE (2014) Possible insect vectors of "Candidatus Phytoplasma asteris" and "Ca. Phytoplasma pruni"-related strains in Lithuania. Žemdirbystè (Agriculture) 101:313-320

Karban R, Strauss SY (2004) Physiological tolerance, climate change, and a northward range shift in the spittlebug, Philaenus spumarius. Ecol Entomol 29:251-254

Keskinen E, Meyer-Rochow VB (2004) Post-embryonic photoreceptor development and dark/light adaptation in the spittle bug Philaenus spumarius (L.)(Homoptera, Cercopidae). Arthropod Struct Dev 33:405-417

Killiny N, Almeida RP (2009) Xylella fastidiosa afimbrial adhesins mediate cell transmission to plants by leafhopper vectors. Appl Environ Microb 75:521-528

Killiny N, Prado SS, Almeida RP (2010) Chitin utilization by the insect-transmitted bacterium Xylella fastidiosa. Appl Environ Microb 76:6134-6140

Killiny N, Rashed A, Almeida RP (2012) Disrupting the transmission of a vector-borne plant pathogen. Appl Environ Microb 78:638-643

King DR (1952) The ecology of the Meadow Spittlebug Philaenus leucophthalmus (L.) L Family Cercopidae. PhD thesis, The Ohio State University

Koga R, Bennett GM, Cryan JR, Moran NA (2013) Evolutionary replacement of obligate symbionts in an ancient and diverse insect lineage. Environ Microbiol 15:2073-2081

Kogan M (1998) Integrated pest management: historical perspectives and contemporary developments. Ann Rev Entomol 43:243-270

Krell RK, Boyd EA, Nay JE, Park YL, Perring TM (2007) Mechanical and insect transmission of Xylella fastidiosa to Vitis vinifera. Am J Enol Vitic 58:211-216

Krewer G, Dutcher JD, Chang CJ (2002) Imidacloprid insecticide slows development of pierce's disease in bunch grapes. J Entomol Sci 37:101-112. https://doi.org/10.18474/0749-8004-37.1.101

Labroussaa F, Zeilinger A, Almeida RP (2016) Blocking the transmission of a non-circulative vector-borne plant pathogenic bacterium. Mol Plant Microbe Interacions 29:535-544

Landi F, Prandini A, Paltrinieri S, Mori N, Bertaccini A (2007) Detection of different types of phytoplasmas in stone fruit orchards in northern Italy. Bull Insectol 60:163

Lavigne B (1959) Biology of Philaenus leucophthalmus (L.), in Massachusetts. J Econ Entomol 52:904-907

Lees DR, Dent CS (1983) Industrial melanism in the spittlebug Philaenus spumarius (L) (Homoptera: Aphrophoridae). Biol J Linn Soc 19:115-129

Lewis WJ, Van Lenteren JC, Phatak SC, Tumlinson JH (1997) A total system approach to sustainable pest management. Proc Natl A Sci 94:12243-12248

Lis A, Maryańska-Nadachowska A, Kajtoch L (2015) Relations of Wolbachia infection with Phylogeography of Philaenus spumarius (Hemiptera: Aphrophoridae) populations within and beyond the Carpathian contact zone. Microb Ecol 70(2):509-521

Loconsole G, Saponari M, Boscia D, D’Attoma G, Morelli M, Martelli GP, Almeida RPP (2016) Intercepted isolates of Xylella fastidi$o s a$ in Europe reveal novel genetic diversity. Eur J Plant Pathol 146:85-94
Lopes JRS, Krugner R (2016) Transmission ecology and epidemiology of the citrus variegated chlorosis strain of Xylella fastidiosa. In: Vector-mediated transmission of plant pathogens. pp 195-208

Malone M, Watson R, Pritchard J (1999) The spittlebug Philaenus spumarius feeds from mature xylem at the full hydraulic tension of the transpiration stream. New Phytol 143:261-271

Martelli GP, Boscia D, Porcelli F, Saponari M (2016) The olive quick decline syndrome in south-east Italy: a threatening phytosanitary emergency. Eur J Plant Pathol 144:235-243

Maryańska-Nadachowska A, Kuznetsova VG, Lachowska D, Drosopoulos S (2012) Mediterranean species of the spittlebug genus Philaenus: modes of chromosome evolution. J Insect Sci 12:1-17

Masters GJ, Brown VK, Clarke IP, Whittaker JB, Hollier JA (1998) Direct and indirect effects of climate change on insect herbivores: Auchenorrhyncha (Homoptera). Ecol Entomol 23:45-52

Matteoni JA, Sinclair WA (1988) Elm yellows and ash yellows. In: Hiruki C (ed) Tree mycoplasmas and mycoplasma diseases. University of Alberta Press, Edmonton, pp 19-31

Medler JT (1955) Method of predicting the hatching date of the meadow spittlebug. J Econ Entomol 48:204-205

Mundinger FG (1946) The control of spittle insects in strawberry plantings. J Econ Entomol 39:299-305

Nast J (1972) Palaearctic Auchenorrhyncha (Homoptera) an annotated checklist. Polish Science Publications, Warszawa

Nicoli Aldini R, Guardiani MC, Cravedi P (1998) Faunistical notes on the hoppers (Homoptera Auchenorrhyncha) in vineyards in the province of Piacenza. Bollettino di Zoologia Agraria e di Bachicoltura 30:61-68

Nieri R, Mazzoni V, Gordon SD, Krugner R (2017) Mating behavior and vibrational mimicry in the glassy-winged sharpshooter, Homalodisca vitripennis. J Pest Sci 90:887-899

Novotny V (1992) Vertical-distribution of leafhoppers (Hemiptera, Auchenorrhyncha) within a meadow community. Acta Entomol Bohemos 89:13-20

Novotny V, Wilson MR (1997) Why are there no small species among xylem-sucking insects? Evol Ecol 11:419-437

Olmo D, Nieto A, Androver F, Urbano A, Beidos O, Juan A et al (2017) First detection of Xylella fastidiosa on cherry (Prunus avium) and Polygala myrtifolia plants, in Mallorca Island, Spain. Plant Dis 101:1820

Ossiannilsson F (1981) The Auchenorrhyncha (Homoptera) of Fennoscandia and Denmark. Part 2: the families Cicadidae, Cercopidae, Membracidae, and Cicadellidae (excl. Deltocephalinae). Fauna Entomologica Scandinavica 7:223-593

Pagliano G, Alma A (1997) Ricerche etologiche su Gorytini e Alyssonini (Hymenoptera Sphecidae) parassitoidi di Auchenorryncha (Rhynchota Homoptera). Rivista Piemontese di Storia Naturale 18:173-181

Paião FG, Meneguim AM, Casagrande EC, Leite RP (2002) Envolvimento de cigarras (Homoptera, Cicadidae) na transmissão de Xylella fastidiosa em cafeeiro. Fitopatol Bras 27:67

Pavan F (2000) Occurrence on elm and phenology of Auchenorrhyncha potential vectors of the phytoplasma associated with elm yellows disease. Bollettino di Zoologia Agraria e di Bachicoltura 32:59-68

Pavan F (2006) Xylem-feeding auchenorrhyncha potentially involved in Pierce's disease of grapevines in Europe. Bollettino di Zoologia Agraria e di Bachicoltura 38:103-114

Pearson WD (1991) Effect of meadow spittlebug and Australian crop mirid on white clover seed production in small cages. $\mathrm{N} \mathrm{Z} \mathrm{J}$ Agric Res 34:439-444

Phillipson J (1960) A contribution to the feeding biology of Mitopus morio (F) (Phalangida). J Anim Ecol 29:35-43

Ponder KL, Watson RJ, Malone M, Pritchard J (2002) Mineral content of excreta from the spittlebug Philaenus spumarius closely matches that of xylem sap. New Phytol 153:237-242 
Poos FW (1953) The meadow spittlebug, how to control it. U. S. D. A. Leaflet, p 341

Purcell AH (1980) Almond leaf scorch: leafhopper and spittlebug vectors. J Econ Entomol 73:834-838

Purcell AH (1981) Vector preference and inoculation efficiency as components of resistance to Pierce's disease in European grape cultivars. Phytopathology 71:429-435

Purcell AH (1997) Xylella fastidiosa, a regional problem or global threat? J Plant Pathol 79:99-105

Purcell AH, Finlay AH, McLean DL (1979) Pierce's disease bacterium: mechanism of transmission by leafhopper vectors. Science 206:839-841

Purcell AH, Gravena S, Donadio LC (1994) Sharpshooter in citrus crops. In: Citrus-integrated management of insect and mite pests. Bebedouro, Estaçao Experimental de Citricultura, pp 213-229

Puterka GJ, Glenn DM, Sekutowski DG, Unruh TR, Jones SK (2003) Particle film, surround WP, effects on glassy-winged sharpshooter behavior and its utility as a barrier to sharpshooter infestation in grapes. Plant Health Prog. https://doi.org/10.1094/ PHP-2003-0321-RS

Putman WL (1953) Notes on the bionomics of some Ontario Cercopids (Homoptera). Can Entomol 85:244-248

Quartau JA, Borges PA (1997) On the colour polymorphism of Philaenus spumarius (L.)(Homoptera, Cercopidae) in Portugal. Miscellania Zoologica 20:19-30

Ranieri E, Ruschioni S, Riolo P, Isidoro N, Romani R (2016) Fine structure of antennal sensilla of the spittlebug Philaenus spumarius L. (Insecta: Hemiptera: Aphrophoridae). I. Chemoreceptors and thermo-hygroreceptors. Arthropod Struct Dev 45:432-439

Rashed A, Killiny N, Kwan J, Almeida RP (2011) Background matching behaviour and pathogen acquisition: plant site preference does not predict the bacterial acquisition efficiency of vectors. Arthropod Plant Interactions 5:97-106

Robertson A, Gibbs AJ (1937) Spermatogenesis and fertilization in Philaenus spumarius Fallen. J Trop Med Hyg 40:257-262

Rodrigues AS, Silva SE, Marabuto E, Silva DN, Wilson MR, Thompson V et al (2014) New mitochondrial and nuclear evidences support recent demographic expansion and an atypical phylogeographic pattern in the spittlebug Philaenus spumarius (Hemiptera, Aphrophoridae). PLoS ONE 9(6):e98375

Salerno M, Russo V, Sefa V, Lamaj F, Basher N, Verrastro V, Porcelli $\mathrm{F}$ (2017) Zelus renardii an assassin bug candidate for Philaenus spumarius biocontrol. In: European conference on Xylella. Finding answer to a global problem. Palma de Mallorca, 13-15 Nov 2017, pp 22-23

Sanderlin RS, Melanson RA (2010) Insect transmission of Xylella fastidiosa to pecan. Plant Dis 94:465-470

Saponari M, Boscia D, Nigro F, Martelli GP (2013) Identification of DNA sequences related to Xylella fastidiosa in oleander, almond and olive trees exhibiting leaf scorch symptoms in Apulia (southern Italy). J Plant Pathol 95:668

Saponari M, Loconsole G, Cornara D, Yokomi RK, De Stradis A, Boscia D, Bosco D, Martelli GP, Krugner R, Porcelli F (2014) Infectivity and transmission of Xylella fastidiosa by Philaenus spumarius (Hemiptera: Aphrophoridae) in Apulia, Italy. J Econ Entomol 107:1316-1319

Saponari M, Boscia D, Altamura G, D'Attoma G, Cavalieri V, Loconsole G, Zicca S, Dongiovanni C, Palmisano F, Susca L, Morelli M, Potere O, Saponari A, Fumarola G, Di Carolo M, Tavano D, Savino V, Martelli GP (2016) Pilot project on Xylella fastidiosa to reduce risk assessment uncertainties. EFSA Supporting Publications. EN-1013, pp 60

Scholl JM, Medler JT (1947) Spittle bugs in relation to alfalfa seed production in Wisconsin. J Econ Entomol 40:446-448

Schulz CA, Meijer J (1978) Migration of leafhoppers (Homoptera: Auchenorrhyncha) into a new polder. Ecography 1:73-78
Severin H (1950) Spittle-insect vectors of Pierce's disease virus. II. Life history and virus transmission. Hilgardia 19:357-376

Sinclair WA, Griffiths HM (1994) Ash yellows and its relationship to dieback and decline of ash. Annu Rev Phytopathol 32:49-60

Smith RL (ed) (1984) Human sperm competition. In: Sperm competition and the evolution of animal mating systems. Academic Press, San Diego, CA, pp 602-652

Stewart AJA, Lees DR (1988) Genetic control of colour/pattern polymorphism in British populations of the spittlebug Philaenus spumarius (L.)(Homoptera: Aphrophoridae). Biol J Linn Soc 34:57-79

Stewart AJ, Lees DR (1996) The colour/pattern polymorphism of Philaenus spumarius (L.) (Homoptera: Cercopidae) in England and Wales. Philos Trans R Soc B 351:69-89

Strona G, Carstens CJ, Beck PS (2017) Network analysis reveals why Xylella fastidiosa will persist in Europe. Sci Rep 7:71

Svanberg I (2016) Cuckoo spit in Northern European folk biology. In: SLA. pp 117-121

Thompson V (1973) Spittlebug polymorphic for warning coloration. Nature 242:126-128

Thompson V (1994) Spittlebug indicators of nitrogen-fixing plants. Ecol Entomol 19:391-398

Thompson V (2004) Associative nitrogen fixation, C4 photosynthesis, and the evolution of spittlebugs (Hemiptera: Cercopidae) as major pests of neotropical sugarcane and forage grasses. Bull Entomol Res 94:189-200

Tishechkin DYu (2013) Two new species of the genus Philaenus (Homoptera, Aphrophoridae) from Iran. Entomol Rev 1:73-76

Tubajika KM, Civerolo EL, Puterka GJ, Hashim JM, Luvisi DA (2007) The effects of kaolin, harpin, and imidacloprid on development of Pierce's disease in grape. Crop Prot 26:92-99

Van Driesche RG, Prokopy RJ, Coli WM (1987) Potential for increased use of biological control agents in Massachusetts apple orchards. Res Bull Mass Agric Exp Stn 718:6-21

Walker GP (2000) A beginner's guide to electronic monitoring of homopteran probing behavior. In: Walker GP, Backus EA (eds) Principles and applications of electronic monitoring and other techniques in the study of homopteran feeding behavior. Thomas say publications in entomology, Entomological Society of America, Lanham, MD, pp 14-40

Waloff N (1973) Dispersal by flight of leafhoppers (Auchenorrhyncha: Homoptera). J Appl Ecol 10:705-730

Watson R, Pritchard J, Malone M (2001) Direct measurement of sodium and potassium in the transpiration stream of saltexcluding and non-excluding varieties of wheat. J Exp Bot 52:1873-1881

Weaver CR (1951) The seasonal behaviour of meadow spittlebug and its relation to a control method. J Econ Entomol 44:350-353

Weaver CR, King DR (1954) Meadow spittlebug, Philaenus leucophthalmus (L.). Ohio Agric Exp Stat Bull 741:1-99

West J, Lees DR (1988) Temperature and egg development in the spittlebug Philaenus spumarius (L.)(Homoptera: Aphrophoridae). The Entomologist 13:46-51

Whittaker JB (1969) The biology of Pipunculidae (Diptera) parasitising some British Cercopidae (Homoptera). Physiol Entomol 44:17-24

Whittaker JB (1970) Cercopid spittle as a microhabitat. Oikos 21:59-64

Whittaker JB (1973) Density regulation in a population of Philaenus spumarius (L.)(Homoptera: Cercopidae). J Anim Ecol 42:163-172

Wiegert RG (1964) Population energetics of meadow spittlebugs (Philaenus spumarius L.) as affected by migration and habitat. Ecol Monogr 34:217-241

Wilson MC, Shade RE (1967) Relative attractiveness of various luminescent colors to the cereal leaf beetle and the meadow spittle bug. J Econ Entomol 60:578-580 
Wise MJ, Kieffer DL, Abrahamson WG (2006) Costs and benefits of gregarious feeding in the meadow spittlebug, Philaenus spumarius. Ecol Entomol 31:548-555

Witsack W (1973) Experimental and ecological investigations on forms of dormancy in homoptera-cicadina (Auchenorrhyncha). 2. On ovarian parapause and obligatory embryonic diapause in Philaenus spumarius (L.)(Aphrophoridae). Zoologische Jahrbücher: Abteilung für Systematik, Okologie und Geographie der Tiere 100:517-562
Yurtsever S (2000) On the polymorphic meadow spittlebug, Philaenus spumarius (L.)(Homoptera: Cercopidae). Turk J Zool 24:447-460

Zajac MA, Wilson MC (1984) The effects of nymphal feeding by the meadov spittlebug, Philaenus spumarius (L.) on strawberry yield and quality. Crop Prot 3:167-175

Zajac MA, Hall FR, Wilson MC (1989) Heat unit model for the development of meadow spittlebug (Homoptera Cercopidae) on strawberry. Environ Entomol 18:347-350 